\title{
P-005１8歳以上で人工内耳を受けた先天性難聴29例
}

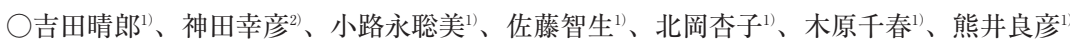

長崎大学 耳鼻咽喉科 ${ }^{1}$ 、神田 $\mathrm{E} \cdot \mathrm{N} \cdot \mathrm{T}$ 医院 ${ }^{2)}$

先天性または言語習得前失聴の成人症例に対する人工内耳は、かつて効果がそしいとされていた。しかし、人工内耳の機 器や音声コード化法の改良、患児に対して早期に診断を行い療育を開始する等の変化により、近年ではこれらの症例にも人 工内耳がある程度有効とする報告もみられている。

今回われわれは、18歳以降に人工内耳手術を受けた 29 例の先天性難聴症例に対し、その術後成績をまとめたので報告す る。症例は、18歳から58歳（平均29.5歳）で人工内耳を受けた29名（女性21名、男性 8 名）である。これらの症例の装用域 值、語音聴取成績、使用機種、療育や教育を評価し、先天性難聴で小児期に人工内耳手術を受け、現在の年齢が 18 歳以上で ある136名と比較を行った。先天性難聴成人例では、術後成績が良好な症例とそうでない症例に差があり、使用している機 種による違いも認められたが、おおむ䅦足できる結果が得られた。症例を適切に選ぶことができれば、先天性難聴成人で あっても人工内耳が有効な症例があると考えらた。

\section{P-006 人工内耳手術を施行した脳表へモジデリン沈着症の一例}

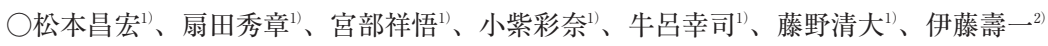
滋賀県立総合病院 耳鼻咽喉科 ${ }^{12}$ 、滋賀県立総合病院研究所 ${ }^{21}$

脳表へモジデリン沈着症は、感音難聴、小脳失調、錐体路障害などを主徵とし、小脳、脳幹部などの軟膜下にへモジデリ ンが沈着する疾患である。発症後は進行性の経過をとり、難聴と小脳失調のためにADLは著しく障害される。本症による 高度難聴例に対する人工内耳の報告が散見されるが、有効とする報告と無効とする報告がある。今回、本症による高度難聴 に対して人工内耳を施行した 1 症例を経験したので報告する。症例は 59 歳女性。初診時の聴力は右スケールアウト、左 61. 3dB。左耳は語音弁別能 $5 \%$ 、自記オージオメトリーはJerger III 型、ABR は $105 \mathrm{~dB}$ で無反応であり後迷路性難聴が疑 われた。半年後には $82.5 \mathrm{~dB}$ まで悪化し、補聴器装用下の会話が困難のため、右耳に人工内耳埋め込み術を施行した。術中 は特記すべき所見なく、全電極挿入し手術終了。術中 EABR 測定では刺激強度を上げることで 1 電極を除いて反応が得ら れた。術後 9 カ月経過時点で、読唇併用で単音節 $70 \%$ の結果で自覚的にも聴取能の改善を認めた。文献的考察を加えて報告 する。

\section{P-007 当科における bFGF 製剤を用いた鼓膜穿孔閉鎖の検討}

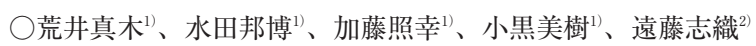

浜松医療センター 耳鼻いんこう科・中耳手術センター ${ }^{11}$ 、静岡済生会病院 中耳手術・耳管センター ${ }^{2)}$

【はじめに】鼓膜穿孔閉鎖のため bFGF 製剂を用いた例を検討した。【症例】 61歳〜88歳、女性 5 例、男性 3 例。内訳は化 学焼灼やパッチで閉鎖しなかった 5 例（術後耳 1 例を含む）、耳管ピン後の穿孔 1 例、鼓膜形成術後再穿孔 1 例、大穿孔 1 例である。【結果】初回閉鎖は 5 例で、閉鎖率は $63.5 \%$ あった。穿孔の残った 2 例でも聴力は改善し、補聴器が使いやす くなるという効果はあった。大穿孔の 1 例には初回無効であった。【考察】後壁削除型・乳突開放型の術後耳は適応に選ば れにくいが、穿孔は閉じたので症例によりトライしてもよいと考えられた。耳管ピン挿入後の穿孔は10〜15\%ほど発生する が、良い適応と思われた。大穿孔で閉じなかった場合、2 回目を施行するか、鼓室形成術に切り替えるか判断が難しい。症 例によると思われるが、本報告の症例では、リティンパ® 2 回目を施行し、足場に耳後部皮下結合織を用いたところ穿孔は 閉鎖した。このような工夫は必要かもしれないが、本来全麻下に行う手術が低侵襲で済めば、大穿孔にも積極的にトライし たい。

\section{P-008 当科における先天性真珠腫症例}

○坪田雅仁、白馬伸洋、鈴木大士、福永陽子、室伏利久、西村幸司 帝京大学医学部附属溝口病院 耳鼻咽喉科

2015年 1 月から 2020 年12月までの期間に当科で手術を施行した先天性真珠腫43症例について検討した。内訳は小览37例、 成人 6 例であり、手術時の年齢は $2 \sim 84$ 歳 (平均13. 5 歳) であった。病期分類としては耳科学会の基準で stageI が 4 例、 stageII が35例、stageIII が 4 例であり、Potsic 分類では stageI が 4 例、stageIII が14例、stageIV が25例であり重症症例が多 かった。手術は43例中 29 例において段階手術とし、一期的手術を施行した 14 例は 4 例が I 型、 4 例が III i 、 2 例が III c、 3 例がIV c にて伝音再建を施行し、1 例は伝音再建を行わなかった。段階手術29例のうち調查期間に 2 回目の手術を施行でき た例は21例であり、14例に再発なく、7 例に遺残を認めた。段階手術例は最終的に 8 例でIII c、9 例でIV c、4 例はIV i に て伝音再建を施行した。術後聴力評価は伝音再建後 1 年以上経過した 32 例にて行い、22例（68.8\%）が成功例と判定され た。 


\section{P-009 当科における先天性真珠腫症例の検討}

○福田航平、廣瀬由紀、田渕経司

筑波大学附属病院 耳鼻咽喉科

先天性真珠腫は内視鏡下耳科手術（TEES）の良い適応であるとの報告がみられるようになり当院においても2018年から 先天性真珠腫に対して TEES を行い始めた。本報告では2001年 1 月から2020年11月に当院で初回手術を行った先天性真珠腫 37症例38耳について検討を行った。平均年齢は7. 1歳（1～20歳)、男性23例、女性14例。左右は19耳ずつと同数で、両側症 例は 1 例であった。真珠腫の主座は後上象限 $63.1 \%$ (24例)、前上象限 $18.4 \%$ （7例）、後下象限 $2.6 \%$ （1例）、前下象限 $2.6 \%$ （1例）、不明 5 例（13.2\%）であった。中耳真珠腫進展度分類2015における stage 分類では stage1 が $15.8 \% （ 6$ 例)、stage2 が73.7\%（28例）、stage3 が5.3\%（2 例)、stage4 は認めなかった（詳細不明は 2 例）。顕微鏡のみでの手術は 28 耳、顕微鏡・内視鏡併用は 3 耳、内視鏡のみは 7 耳であった。術後 1 年以上経過した 31 耳での再発率は $16.1 \%$ （5 例）で あった。

\section{P-010 アブミ骨手術を契機に遺伝学的検査を施行した van der Hoeve 症候群例}

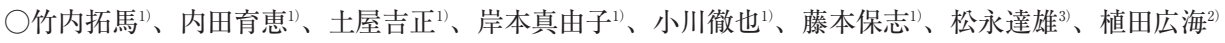
愛知医科大学病院 耳鼻咽喉科 ${ }^{1}$ 、名鉄病院 耳鼻咽喉科 ${ }^{2}$ 、

国立病院機構 東京医療センター 耳鼻咽喉科／臨床研究センター聴覚障害研究室 ${ }^{33}$

Van der Hoeve 症候群は骨形成不全症 1 型に相当すると考えられており、常染色体優性遺伝で青色強膜、骨脆弱性による 多発骨折、難聴を 3 主徵とする疾患であるが、3 主徴の揃わない不全型発症例も多い。今回母親のアブミ骨手術を契機に青 色強膜のみの息子とともに遺伝学的検査を検討した症例を経験したので報告する。症例は50歳女性。4 年前からの難聴を自 覚して他院を受診し、耳硬化症が疑われ、聴力の定期検查で経過観察されていた。経過中に青色強膜を指摘され、家族歴も 認め、アブミ骨手術の要否相談のため当院に紹介された。家族歴として、少なくとも 6 人の親族に青色強膜があることが分 かったが、3主徴が揃っていたのは本症例のみであった。その後、右耳硬化症に対してアブミ骨手術を施行し、入院中に van der Hoeve 症候群と遺伝子異常の関与について説明を行った。本症例と息子の 2 名が遺伝学的検査を受け、解析で得た 遺伝子バリアントの結果とともに文献的考察を含めて報告する。

\section{P-011 外耳・中耳奇形を認めた Fraser 症候群の一例}

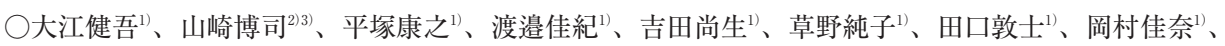
田中千智1、藤川詩織1

日本赤十字社 大阪赤十字病院 耳鼻咽喉科・頭頸部外科 ${ }^{1)}$ 、神戸市立医療センター中央市民病院 ${ }^{2} 、$ 神戸医療産業都市推進機構 ${ }^{3}$

Fraser 症候群は潜在眼球症、尿生殖器奇形、合指症などを主症状とし、全盲を来すまれな常染色体劣性遺伝疾患であ る。Fraser 症候群では外耳奇形や難聴の報告もあるが不明な点が多い。われわれは、難聴と耳漏を主訴とし、両側外耳・ 中耳奇形を認めた Fraser 症候群の1例を経験したので報告する。症例は14歳女览で生来難聴を有していたが放置してい た。両耳に外耳道狭窄と混合性難聴を認め、CTでは両側外耳道狭窄と耳小骨奇形、左外耳道真珠腫、右中耳軟部陰影を認 めた。左耳の手術では軟骨部外耳道の狭窄による外耳道真珠腫とツチ骨柄部分欠損、キヌタ骨長脚短縮、アブミ骨上部構造 偏倚を認めたため左鼓室形成術 III c 型を施行した。一方、右耳の手術では左耳と同様に外耳道狭窄と耳小骨奇形を認め、さ らに緊張部型真珠腫 StageIb、弛緩部型真珠腫 StageIb を認めたため、右鼓室形成術 III i - M 型を施行した。Fraser 症候群 は視力障害だけでなく、難聴や真珠腫が合併する可能性があり、適切な耳鼻科的な介入が重要と考えられる。

\section{P-012スキャッタグラムを用いた中耳術後聴力評価}

○美内慎也、西村理宇、池畑美樹、阪上雅史、都築建三

兵庫医科大学 耳鼻咽喉科・頭頸部外科

【はじめに】縦軸が気導純音聴力、横軸が語音明瞭度にて表記されるスキャッタグラムを用いて、鼓室形成術、アブミ骨 手術の術後聴力評価を行った。【対象・方法】2016年 1 月から2019年10月の間に、当科で一期的初回手術を施行し、術前と 術後 1 年以降に純音聴力検査および語音聴力検査の両者を施行した慢性中耳炎28耳、真珠腫性中耳炎19耳、耳硬化症16耳を 対象とした。日本耳科学会術後聴力成績判断基準（2010）と、スキャッタグラムにて術後聴力を評価した。【結果】耳科学 会判定基準での成功例は、慢性中耳炎25/28（89.3\%)、真珠腫 $9 / 19$ (47.4\%)、耳硬化症14/16（87.5\%）であった。スキ ヤッタグラムにて純音聴力・語音明瞭度ともに改善したものはそれぞれ11/28 (39.3\%)、2/19（10.5\%)、2/16 (12.5\%)、ともに悪化はそれぞれ0/26 $(0.0 \%) 、 3 / 19(15.8 \%) 、 3 / 16(18.8 \%)$ であった。スキャッタグラムと従来 の聴力評価との検討について提示する。 